\title{
PERANCANGAN SISTEM PEMINJAMAN DAN PENGEMBALIAN REKAM MEDIS RAWAT INAP RUMAH SAKIT HUMANA PRIMA BANDUNG
}

\author{
Haini DwiJuliani Hendayal ${ }^{1 *}$, Yuda Syahidin ${ }^{2}$, Meira Hidayati ${ }^{3}$ \\ Politeknik Piksi Ganesha Bandung, Indonesia ${ }^{1,2,3}$ \\ hdhendaya@piksi.ac.id ${ }^{1 *}$, yuda.syahidin@piksi.ac.id ${ }^{2}$, meira.hidayati@piksi.ac.id ${ }^{3}$
}

Received: 26-07-2021

Revised : 22-10-2021

Accepted: 23-10-2021

\begin{abstract}
Abstrak
Latar Belakang: Peminjaman dan pengembalian rekam medis pasien rawat inap di RSIA Humana Prima Bandung terdapat beberapa kendala, seperti sistem yang masih menggunakan sistem manual dan masih menggunakan buku ekspedisi belum sampai pada pemanfaatan sistem informasi komputerisasi. Begitupun dalam proses pengembalian terkadang masih terjadi ketidaktepatan waktu pengembalian rekam medis. Sebab hal itu dibutuhkannya perancangan sistem informasi peminjaman dan pengembalian rekam medis pasien rawat inap, agar mempermudah petugas dalam pencatatan, peminjaman, pengembalian, dan memonitoring rekam medis dengan baik.

Tujuan: Tujuan umum dari penelitian ini adalah merancang sistem informasi peminjaman dan pengembalian berkas rekam medis rawat inap RSIA Humana Prima Bandung.

Metode: Metode penelitian yang digunakan adalah metode kualitatif dengan pendekatan deskriptif. Metode pengumpulan data dilakukan dengan cara observasi dan metode pengembangan yang digunakan adalah metode waterfall.
\end{abstract}

Hasil: Hasil dari penelitian ini adalah merancang dan membuat sistem informasi peminjaman dan pengembalian rekam medis pasien rawat inap menggunakan microsoft visual studio 2010 yang diharapkan agar memudahkan petugas rekam medis untuk melaksanakan tugasnya.

Kesimpulan: Kesimpulan dari penelitian ini yaitu peminjaman dan pengembalian rekam medis pasien rawat inap di RSIA Humana Prima Bandung. Saat ini mempunyai pengolahan data yang cukup baik namun masih terdapat kendala untuk peminjaman dan pengembalian seperti sistem yang berjalan tidak sesuai dengan kenyataan yang ada dan membuat proses peminjaman dan pengembalian rekam medis dilakukan dengan cara manual. Begitupun dalam proses pengembalian rekam medis yang telah selesai dipinjam masih terjadi keterlambatan waktu pengembalian. Selain itu belum adanya sistem informasi peminjaman dan pengembalian rekam medis dengan laporan yang memadai sehingga sangat sulit untuk memonitoring.

Kata kunci: perancangan; peminjaman dan pengembalian; 
visual studio 2010 .

\begin{abstract}
Background: Borrowing and returning inpatient medical records at RSIA Humana Prima Bandung, there are several obstacles, such as systems that still use manual systems and still use expedition books that have not yet reached the utilization of computerized information systems. Likewise in the process of returning sometimes, there is still an inaccuracy in the time of returning medical records. For this reason, it is necessary to design an information system for borrowing and returning inpatient medical records, in order to make it easier for officers to record, borrow, return, and monitor medical records properly.
\end{abstract}

Objective: The general objective of this research is to design an information system for borrowing and returning inpatient medical record files at RSIA Humana Prima Bandung.

Methods: The research method used is a qualitative method with a descriptive approach. The method of data collection is done by observation and the development method used is the waterfall method.

Results: The results of this study are to design and create an information system for borrowing and returning inpatient medical records using Microsoft Visual Studio 2010 which is expected to make it easier for medical record officers to carry out their duties.

Conclusion: The conclusion of this study is borrowing and returning medical records of inpatients at RSIA Humana Prima Bandung. Currently, it has good data processing, but there are still obstacles for borrowing and returning such as the system that is running not in accordance with the existing reality and making the process of borrowing and returning medical records done manually. Likewise, in the process of returning medical records that have been borrowed, there is still a delay in the return time. In addition, there is no information system for borrowing and returning medical records with adequate reports, making it very difficult to monitor.

Keywords: design; borrowing and returning; visual studio 2010.

*Correspondent Author: Haini DwiJuliani Hendaya Email: hdhendaya@piksi.ac.id

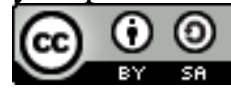

\title{
PENDAHULUAN
}

Saat ini teknologi berbasis komputer telah banyak dimanfaatkan dalam berbagai bidang pelayanan kesehatan terutama rumah sakit (Putra, 2019). Sebab diharapkan dapat memberikan informasi yang diperlukan oleh pelayanan kesehatan yang akurat, relevan dan 
terintegrasi (Khanifatuzzahro, 2015). Demikian hal itu kita dituntut untuk mengikuti perkembangan zaman dengan hadirnya informasi terbaru dalam dunia kesehatan.

Rumah sakit merupakan suatu institusi perawatan kesehatan profesional yang diberikan kepada masyarakat yang memerlukan pelayanan tersebut (Rikomah, 2017). Rumah sakit merupakan institusi pelayanan kesehatan yang menyelenggarakan pelayanan kesehatan perseorangan dengan cara paripurna yang menyediakan pelayanan rawat inap, rawat jalan dan gawat darurat, serta institusi pelayanan kesehatan bagi masyarakat dengan karakteristik tertentu yang dipengaruhi oleh pertumbuhan ilmu pengetahuan kesehatan, kemajuan teknologi, serta kehidupan sosial ekonomi warga yang wajib senantiasa dapat menaikkan pelayanan yang lebih bermutu serta terjangkau oleh warga supaya terwujud derajat kesehatan yang setinggi-tingginya (Indonesia, 2009).

Catatan ialah tulisan-tulisan yang dibuat oleh dokter ataupun dokter gigi perihal tindakan-tindakan yang diberikan kepada penderita dalam rangka pelayanan kesehatan. Rekam medis pasien harus siap apabila pasien berobat kembali. Tenaga kesehatan bakal kesulitan dalam melakukan pengobatan sebelum mengetahui riwayat penyakit, tindakan maupun terapi yang dilakukan kepada penderita yang terdapat dalam dokumen rekam medis. Perihal penting dalam rekam medis adalah ketersediaannya saat dibutuhkan pengisiannya. Kegunaan dari rekam medis itu sendiri bisa dilihat dari bermacam aspek ialah aspek administrasi, aspek hukum, aspek riset, pembelajaran serta dokumentasi, pelayanan rekam medis di rumah sakit meliputi registrasi pasien sampai penyelenggaraan penyimpanan dokumen rekam medis (Setiatin \& Syahidin, 2017).

Mengingat begitu pentingnya rumah sakit serta perannya untuk masyarakat, maka mutu kualitas dan kelancaran pelayanan rumah sakit harus ditingkatkan demi terciptanya tertib administrasi dan kenyamanan untuk pengguna jasa. Salah satu untuk menunjang hal tersebut maka diadakannya rekam medis, seperti yang tertuang dalam PERMENKES, No.269 Tahun 2008 tentang rekam medis, dalam pertimbangannya menyebutkan bahwa "Peningkatan mutu pelayanan kesehatan harus disertai adanya sarana penunjang yang memadai penyelenggaraan rekam medis setiap sarana pelayanan kesehatan" (Permenkes, 2008).

Rekam medis adalah keterangan baik yang tertulis maupun yang terekam tentang identitas, anamnesa, penentuan fisik laboratorium, diagnosa segala pelayanan dan tindakan medis yang diberikan kepada pasien dan pengobatan baik yang dirawat inap, rawat inap maupun yang mendapatkan pelayanan gawat darurat (Noviasari et al., 2016). Ketidaktepatan pengembalian rekam medis juga mempengaruhi bagian filing karena jika ada pasien yang akan kontrol post rawat inap terkadang berkas belum di kembalikan ke unit rekam medis sehingga bagian filing harus menghubungi perawat (Rosalin \& Herfiyanti, 2021).

Akan tetapi berdasarkan pengamatan yang dilakukan oleh penulis selama menjalani penelitian di RSIA Humana Prima Bandung sudah mempunyai sistem yang cukup baik dalam sistem pengendalian, namun ditemukan beberapa kendala yang ada di Rumah Sakit tersebut yaitu sistem peminjaman dan pengembalian rekam medis yang masih menggunakan sistem manual, yaitu masih menggunakan buku ekspedisi belum sampai pada pemanfaatan sistem informasi komputerisasi. Begitupun dalam proses pengembalian terkadang masih terjadi keterlambatan pengembalian apabila jika terjadi ketidaktepatan waktu pengembalian rekam medis dari poli unit ke unit rekam medis, maka sistem pelayanan akan terhambat dan terganggu sehingga waktu tunggu pasien menjadi lama, dan dimana seharusnya rekam medis yang telah dipinjam dikembalikan paling lambat 2 × 24 jam untuk rekam medis rawat inap dari waktu peminjaman. Selain itu belum adanya sistem informasi peminjaman dan pengembalian rekam medis dengan laporan yang memadai sehingga sulit untuk memonitoring rekam medis dengan baik.

Berdasarkan hasil penelitian yang dilakukan di Rumah Sakit Ibu dan Anak Humana Prima Bandung menunjukkan bahwa pengelolaan peminjaman serta pengembalian rekam medis tidak berjalan sesuai Standar Operasional Prosedur (SOP) yang 
berlaku, dimana berkas rekam medis yang dipinjam tidak dicatat di buku ekspedisi sehingga mengakibatkan tidak diketahuinya berkas rekam medis mana saja yang dipinjam. Saat ini peminjaman rekam medis masih disesuaikan dari sistem pendaftaran masuk dari database yang sudah ada, di samping itu ada rekam medis yang masih berada di poliklinik dan belum kembali ke ruangan rekam medis lebih dari 1x24 jam, sehingga ketika pasien datang berobat, rekam medis tidak ditemukan dalam penyimpanan sehingga kadang petugas mengira berkas rekam medis salah masuk rak filing.

Hal tersebut disebabkan petugas tidak memakai tracer untuk mengetahui dokumen yang sedang dipinjam, sehingga mempersulit petugas dalam melaksanakan pencarian dokumen yang keluar dari rak filing dan mempersulit. Petugas ketika mengembalikan dokumen rekam medis, serta belum tersedianya sistem informasi peminjaman serta pengembalian berkas rekam medis. Sistem informasi pada zaman sekarang sangat diperlukan, sebab bias berguna untuk memudahkan petugas penyimpanan untuk mengawasi maupun mengatur berkas rekam medis yang dipinjam telah dikembalikan atau belum. Serta sistem informasi ini berfungsi agar kedepannya rekam medis yang dipinjam atau belum kembali dapat diketahui dari awal dan dapat segera diambil pada hari itu juga sebelum dilakukannya pencarian rekam medis. Berdasarkan fakta-fakta yang telah dideskripsikan, maka penulis tertarik untuk "Perancangan Sistem Informasi Peminjaman dan Pengembalian Rekam Medis Rawat inap Menggunakan Microsoft Visual Studio 2010 di Rumah Sakit Ibu dan Anak Humana Prima Bandung" yang bertujuan untuk memudahkan petugas dalam penulisan, peminjaman, pengembalian, mengawasi dan mengendalikan rekam medis.

Demikian hal itu berdasarkan uraian tersebut, maka diperlukannya rekam medis yang terkomputerisasi agar meminimalisir keterlambatan. Sistem peminjaman dan pengembalian rekam medis pasien rawat inap dapat disempurnakan dengan mengimplementasikan pada teknologi komputer, dengan merancang sistem informasi yang saling terintegrasi. Maka untuk membantu dalam proses peminjaman dan pengembalian rekam medis rawat inap akan merencanakan atau membuat sistem informasi peminjaman dan pengembalian rekam medis rawat inap. Dengan fungsi adanya sistem yang akan dibuat bisa mempermudah dan mempercepat proses peminjaman dan pengembalian rekam medis rawat inap.

\section{METODE PENELITIAN}

Metode pengumpulan data yang dilakukan dalam penelitian ini merupakan metode penelitian kualitatif melalui pendekatan deskriptif, yang menganalisis dan menggambarkan objek penelitian yaitu prosedur peminjaman serta pengembalian rekam medis pasien rawat jalan di Rumah Sakit Ibu dan Anak Humana Prima Bandung. Penelitian kualitatif adalah penelitian tentang riset yang bersifat deskriptif dan cenderung menggunakan analisis dengan pendekatan induktif. Proses dan makna (prospektif subyek) lebih difokuskan dalam penelitian kualitatif. Landasan teori digunakan sebagai pemandu supaya fokus penelitian sesuai dengan fakta di lapangan. Tidak hanya itu landasan teori pula berguna untuk memberikan cerminan umum mengenai latar belakang riset serta sebagai bahan pembahasan hasil riset (Kasmawati, 2014). Serta penelitian kualitatif berupaya mendeskripsikan dan menginterpretasi objek sesuai dengan apa adanya.

Teknik pengumpulan data yang digunakan penulis dalam penelitian ini yaitu dengan observasi, wawancara dan studi pustaka.

1. Observasi

Penulis melakukan pengamatan serta mengkaji permasalahan secara langsung terhadap objek penelitian yaitu pelayanan peminjaman dan pengembalian rekam medis rawat jalan di Rumah Sakit Ibu dan Anak Humana Prima Bandung.

2. Wawancara 
Penulis melakukan wawancara atau interview dengan metode tanya jawab secara langsung terkait penelitian. Wawancara tersebut dilakukan kepada Kepala Unit Rekam Medis, petugas bagian Administrasi Umum Rekam Medis dan petugas Penyimpanan Rekam Medis tujuannya adalah untuk memperoleh informasi yang dibutuhkan mengenai sistem informasi peminjaman serta pengembalian rekam medis rawat jalan di Rumah Sakit Ibu dan Anak Humana Prima Bandung.

3. Studi Pustaka

Penulis melihat dan mempelajari dari buku-buku ilmiah, jurnal, serta kajian-kajian pustaka lainnya yang ada kaitannya dengan variabel yang diteliti.

\section{Metode Pengembangan Perangkat Lunak}

Perancangan serta pembuatan sistem informasi menggunakan metode waterfall. Alasan peneliti menggunakan metode ini disebabkan adanya kesamaan dengan sifat penelitian yang dilakukan. Dalam pengembangannya metode waterfall mempunyai beberapa tahapan yang terstruktur: Requirements definition (analisis kebutuhan) dalam langkah ini adalah analisis terhadap keperluan sistem yang hendak membuat dokumen user requirement ataupun dapat dikatakan sebagai informasi yang berhubungan dengan kemauan user dalam perancangan sistem. System and software design (desain sistem) proses design bakal menerjemahkan ketentuan keperluan sebuah pembuatan perangkat lunak yang dapat diprediksi sebelum membuat coding.

Langkah inilah yang hendak dipakai programmer untuk melaksanakan kreativitas perancangan sistemnya. Implementation and unit testing (pembuatan program) coding adalah penerjemahan desain ke dalam isyarat yang dapat dipahami oleh komputer, sesudah pengkodean telah selesai dilakukan, selanjutnya akan dicoba testing atas sistem yang sudah dirancang. Testing dilakukan agar mengetahui kesalahan-kesalahan terkait sistem itu serta setelah itu dapat diperbaiki. Integration and system testing (penerapan program)tahapan ini dapat dilakukan di akhir dalam pembuatan sistem, sesudah melakukan analisis, design serta pengkodean hingga sistem telah dipakai oleh user. Operation and maintenance (pemeliharaan) setelah analisis, design serta pengkodean untuk itu sistem yang telah dibuat akan dijalankan oleh user. Selanjutnya software yang sudah jadi wajib dilakukan perawatan secara teratur. Selain itu, metode ini harus diselesaikan tahap demi tahap yang artinya tidak dapat melompati ke tahap selanjutnya sebelum tahap yang sedang dikerjakan telah benarbenar selesai (Wijayanti et al., 2021).

Tahapan dalam pembuatan sistem informasi peminjaman dan pengembalian rekam medis pasien rawat inap yaitu menggunakan metode pengembangan sistem yaitu metode air terjun atau yang sering disebut metode waterfall. Menurut (Jimmy Tri Pradana, 2019), model proses waterfall yang juga dikenal dengan classic life cycle. adalah model klasik yang bersifat sistematis, berurutan dalam mengembangkan perangkat lunak. Model ini melingkupi aktivitas-aktivitas seperti ditunjukan pada gambar berikut :

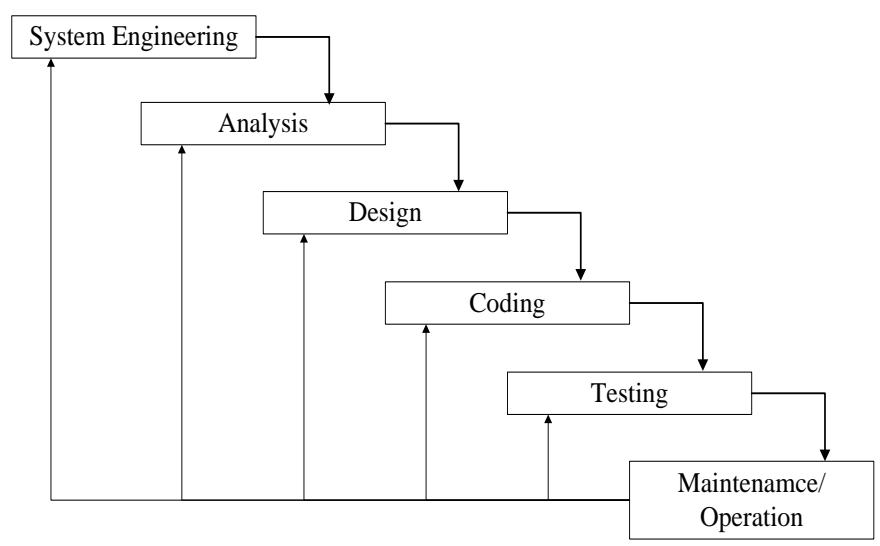

Gambar 1. Waterfall Presman, (2010)

Perancangan Sistem Peminjaman dan Pengembalian Rekam Medis Rawat Inap Rumah Sakit Humana Prima Bandung 


\section{HASIL DAN PEMBAHASAN}

\section{A. Analisis Sistem yang Berjalan}

Berdasarkan analisis yang dilakukan di RSIA Humana Prima Bandung dalam pengolahan data peminjaman dan pengembalian rekam medis rawat inap. Dapat disimpulkan analisis sebagai berikut:

1. Peminjaman dan pengembalian rekam medis masih dilakukan dengan sistem manual, karena sistem yang berjalan tidak sesuai dengan kenyataan yang ada sehingga proses peminjaman dan pengembalian masih menggunakan buku ekspedisi. Sehingga perlu adanya sistem komputerisasi agar lebih efisien.

2. Proses pengembalian sistem yang berjalan masih sering terjadi keterlambatan dalam pengembalian. Proses melakukan monitoring rekam medis yang masih dipinjam atau sudah dikembalikan, petugas melakukan pengecekan melalui data peminjaman dan pengembalian yang ada di buku ekspedisi. Seharusnya pengembalian dikembalikan selambat-lambatnya $2 \times 24$ jam untuk rekam medis rawat inap.

3. Sistem yang berjalan pun belum adanya sistem peminjaman dan pengembalian dengan laporan memadai.

Sebab hal itu dari uraian permasalahan di atas dapat menyimpulkan perlu adanya perancangan sistem informasi peminjaman dan pengembalian rekam medis dengan menggunakan sistem komputerisasi secara menyeluruh, yang lebih baik dari sistem yang berjalan saat ini agar proses peminjaman, laporan, dan pengembalian rekam medis dapat berjalan dengan cepat dan akurat. Guna meningkatkan sistem kerja di RSIA Humana Prima Bandung. Menurut (Hutahaean, 2015), sistem informasi adalah suatu sistem dalam organisasi yang mempertemukan kebutuhan pengolahan transaksi harian, mendukung operasi, bersifat manajerial, dan kegiatan strategi dari suatu organisasi dan menyediakan pihak luar tertentu dengan laporan-laporan yang dibutuhkan”.

\section{B. Perancangan Sistem Informasi}

\section{Flowmap}

Flowmap adalah diagram yang menunjukan arus pekerjaan secara keseluruhan dari sistem. Diagram ini menjelaskan urutan dari prosedur - prosedur yang ada di dalam sistem. Flowmap menunjukan apa yang dikerjakan di sistem (Yanuar, 2017). Berikut merupakan flowmap yang diusulkan dalam sistem peminjaman dan pengembalian rekam medis pasien rawat inap : 
Haini DwiJuliani Hendayal, Yuda Syahidin, Meira Hidayati /Cerdika: Jurnal Ilmiah Indonesia, 1(11), 1497 - 1515

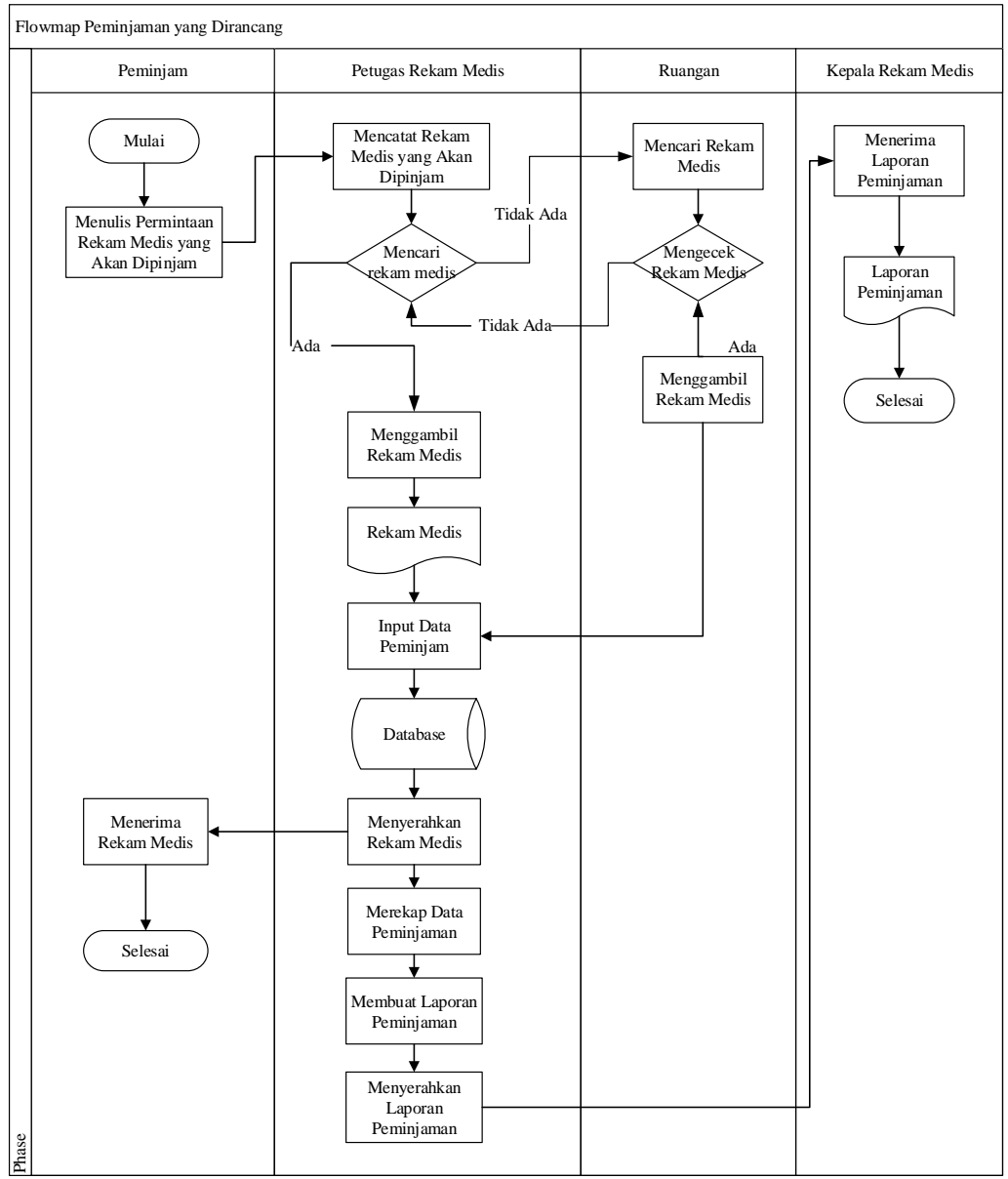

Gambar 2. Flowmap Sistem yang Diusulkan

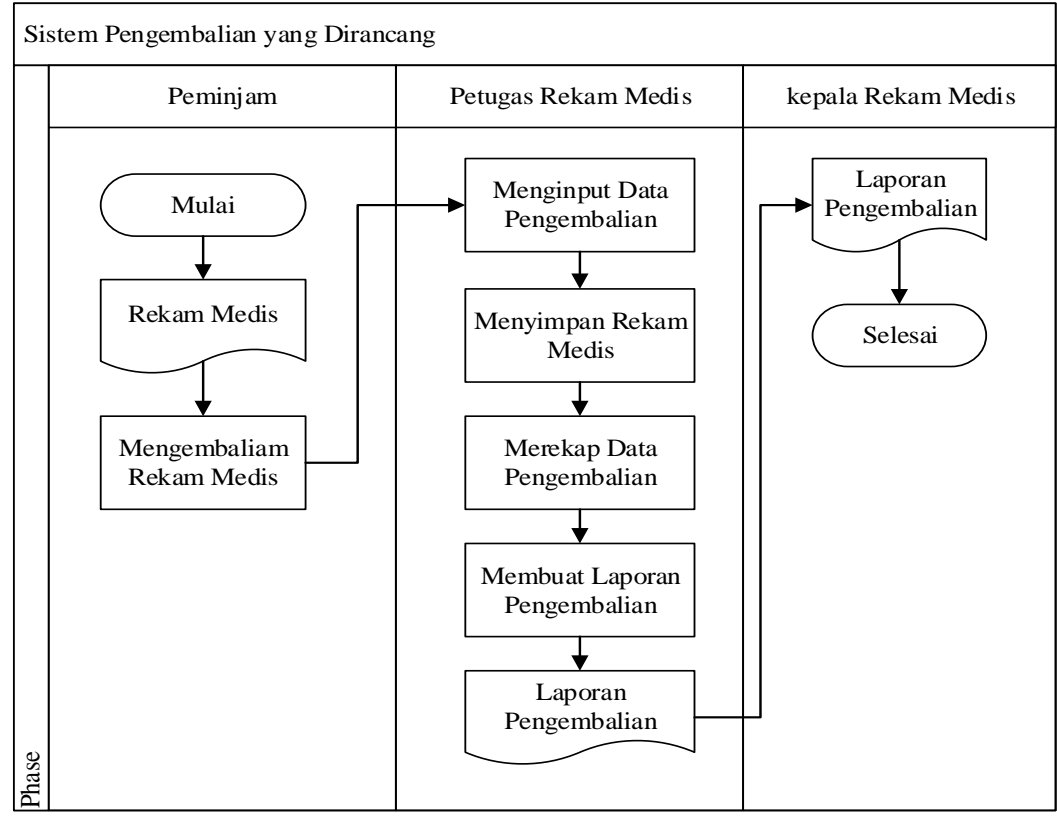

Gambar 3. Flowmap Sistem yang Diusulkan

2. Diagram Konteks Sistem yang Diusulkan 


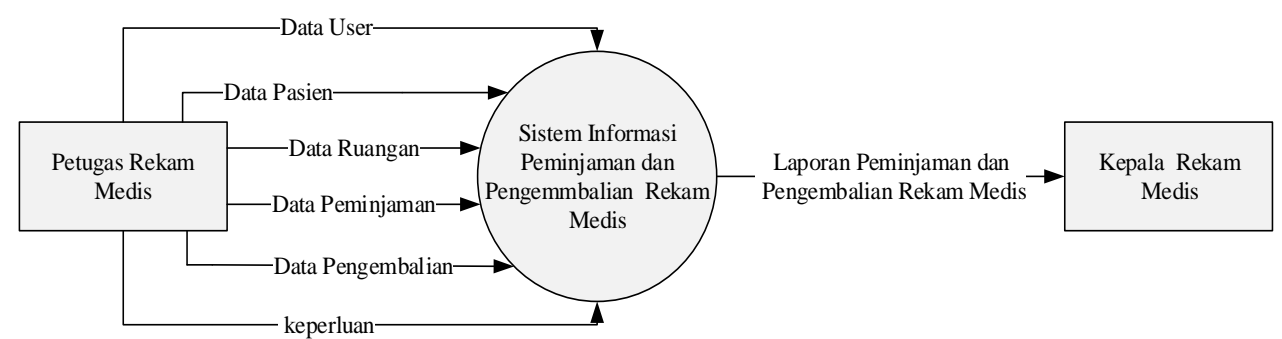

Gambar 4. Diagram konteks Sistem yang Diusulkan

3. Data Flow Diagram (DFD)

Data Flow Diagram (DFD) adalah perangkat-perangkat analisis dan perancangan yang terstruktur sehingga memungkinkan peng-analisa sistem memahami sistem dan sub sistem secara visual sebagai suatu rangkaian aliran data yang saling berkaitan (Yanuar, 2017). Berikut merupakan DFD yang diusulkan dalam sistem informasi peminjaman dan pengembalian rekam medis pasien rawat inap:

DFD Level 0 Sistem Yang Diusulkan

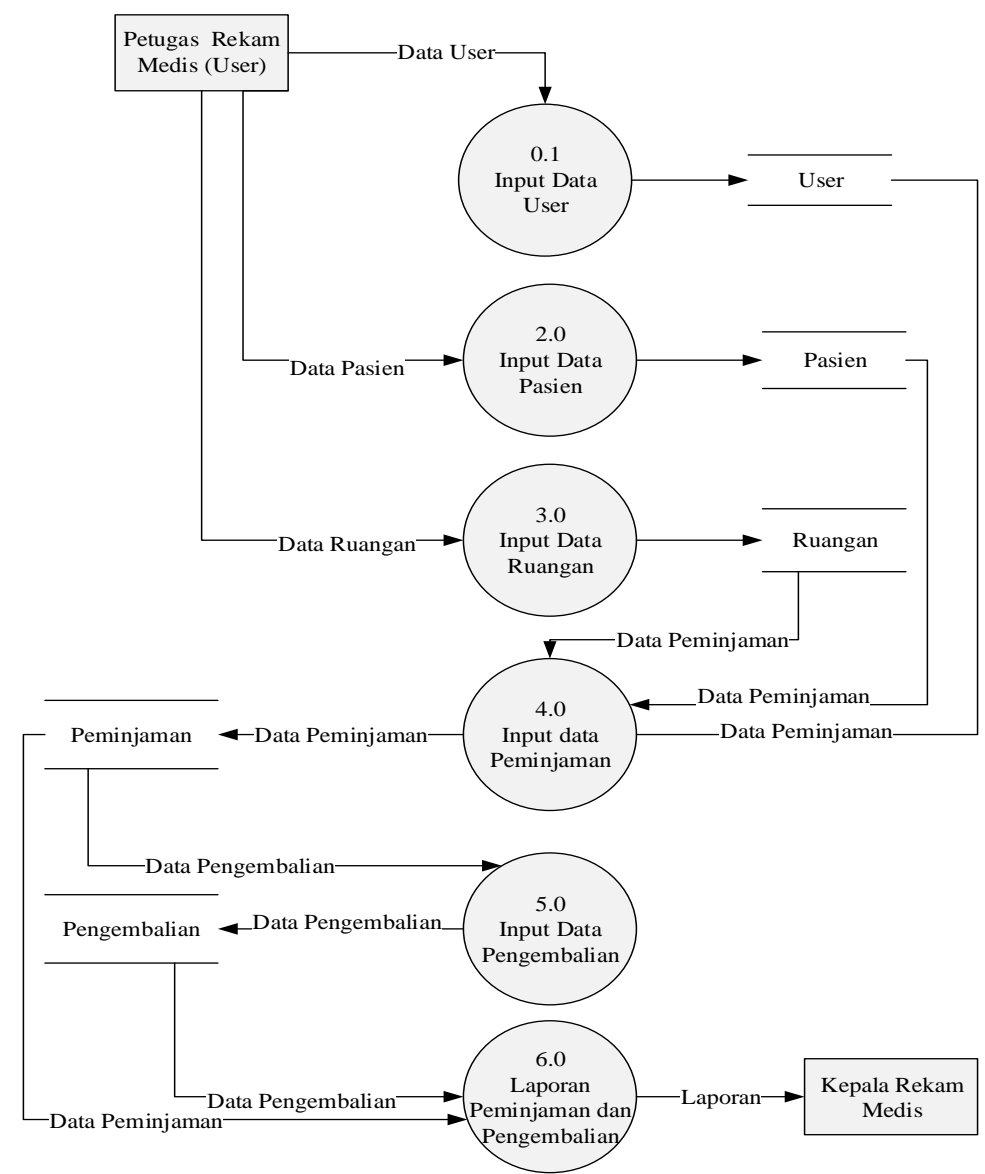

Gambar 5. DFD Level 0 Sistem yang Diusulkan

Perancangan Sistem Peminjaman dan Pengembalian Rekam Medis Rawat Inap Rumah Sakit Humana Prima Bandung 
4. DFD Level 1 Proses 1.0 Sistem Yang Diusulkan

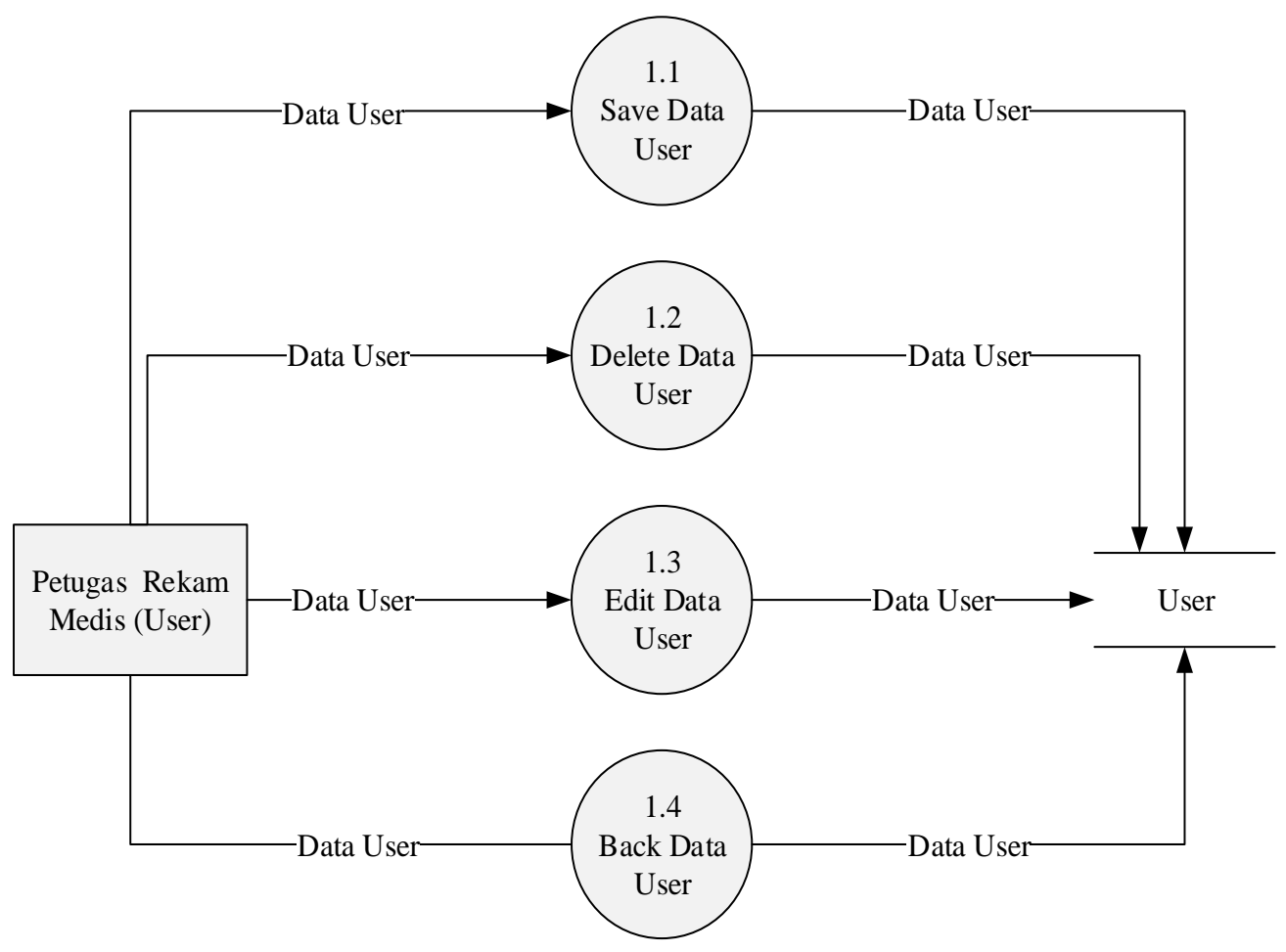

Gambar 6. DFD Level 1 Proses 1.0 Sistem yang Diusulkan

5. DFD Level 1 Proses 2.0 Sistem yang Diusulkan

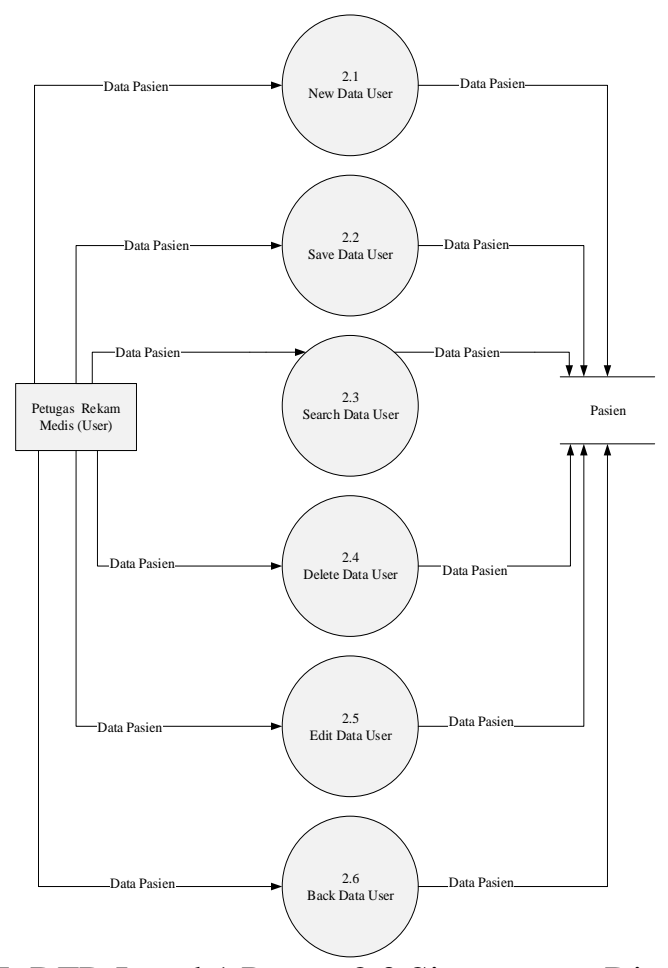

Gambar 7. DFD Level 1 Proses 2.0 Sistem yang Diusulkan

6. DFD Level 1 Proses 3.0 Sistem yang Diusulkan

Perancangan Sistem Peminjaman dan Pengembalian Rekam Medis Rawat Inap Rumah Sakit Humana Prima Bandung 
Haini DwiJuliani Hendayal, Yuda Syahidin, Meira Hidayati /Cerdika: Jurnal Ilmiah Indonesia, 1(11), 1497 - 1515

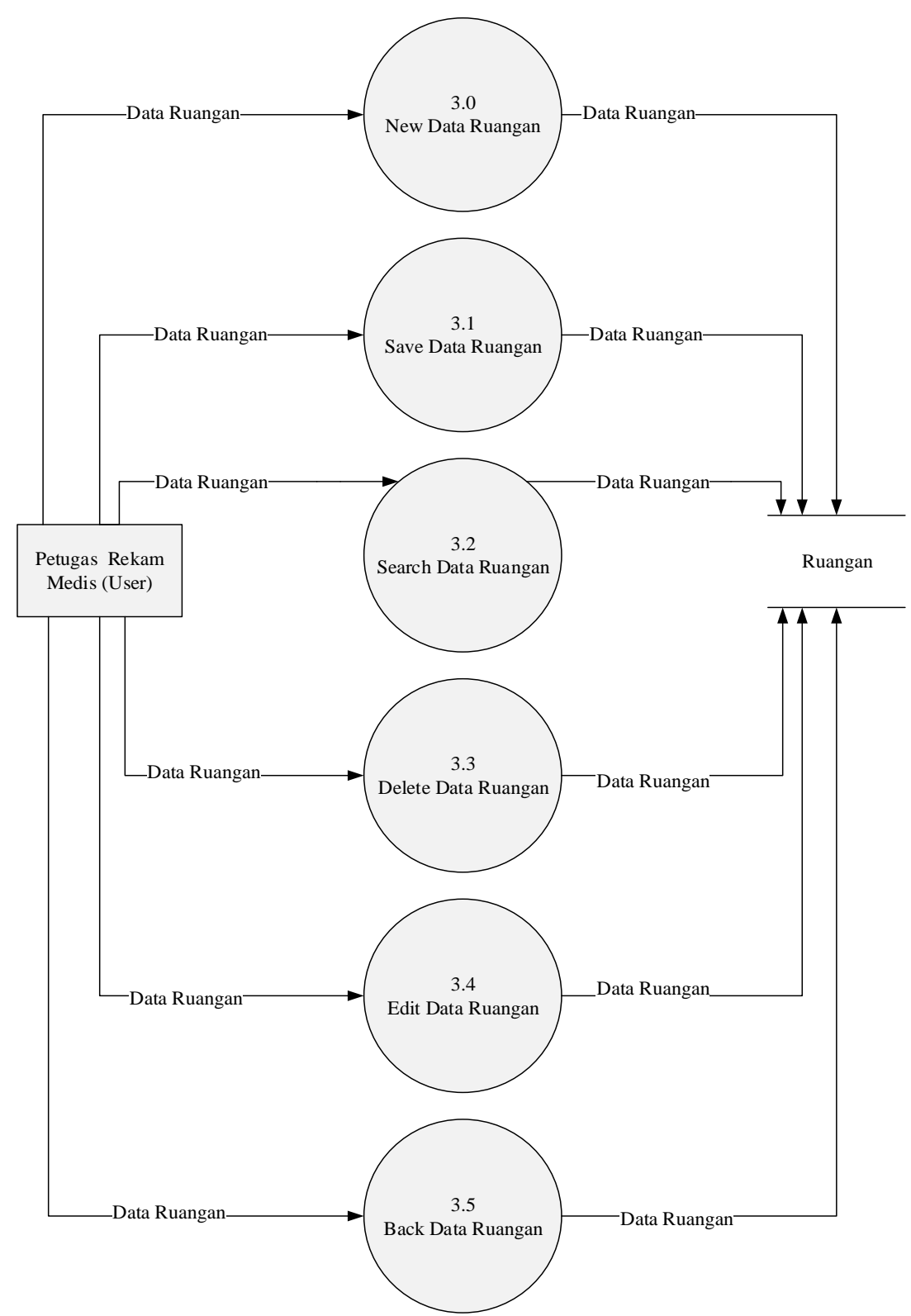

Gambar 8. DFD Level 1 Proses 3.0 Sistem yang Diusulkan 
Haini DwiJuliani Hendayal, Yuda Syahidin, Meira Hidayati /Cerdika: Jurnal Ilmiah Indonesia, 1(11), 1497 - 1515

7. DFD Level 1 Proses 4.0 Sistem yang Diusulkan

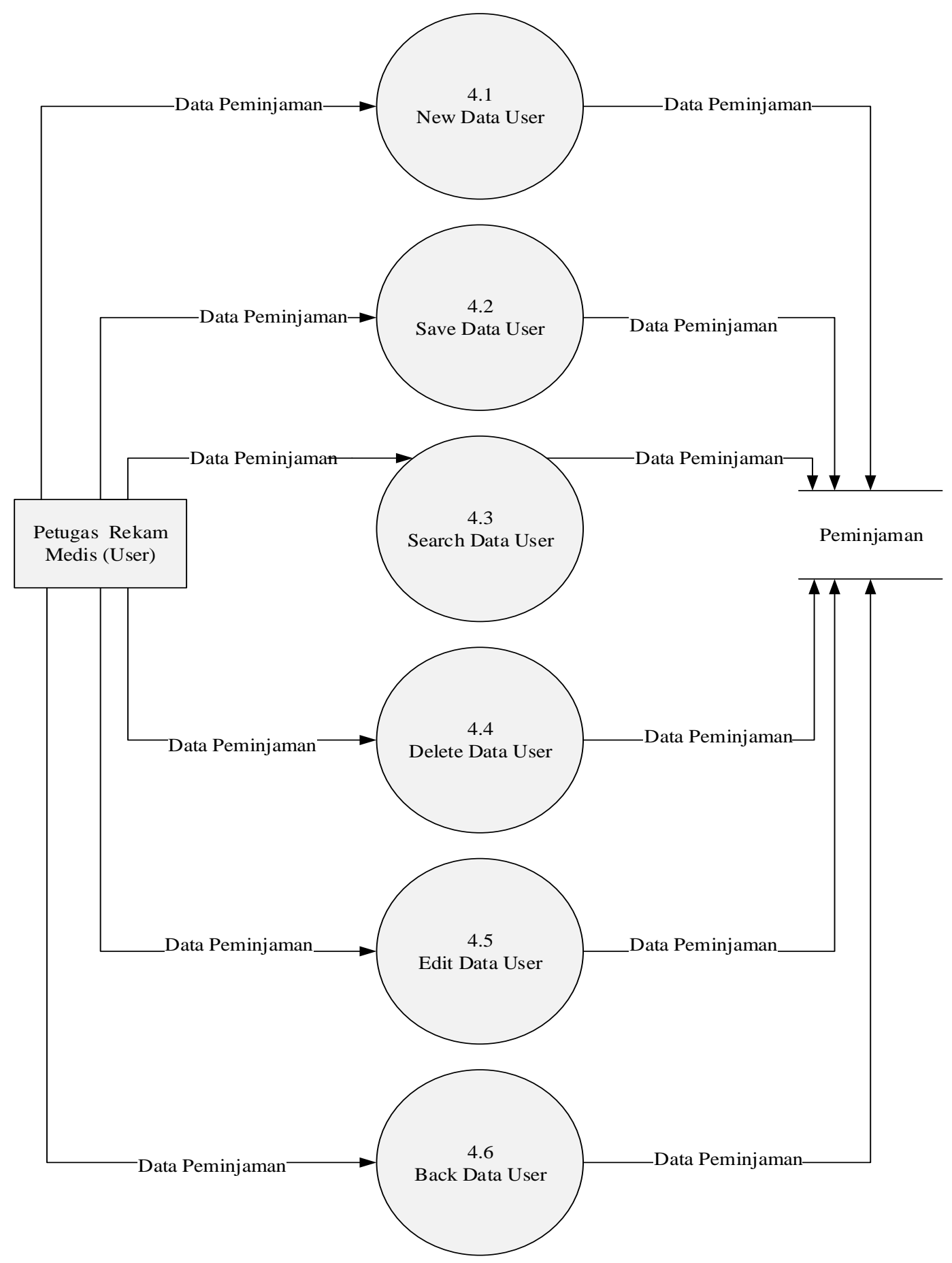

Gambar 9. DFD Level 1 Proses 4.0 Sistem yang Diusulkan 
Haini DwiJuliani Hendayal, Yuda Syahidin, Meira Hidayati /Cerdika: Jurnal Ilmiah Indonesia, 1(11), 1497 - 1515

8. DFD Level 1 Proses 5.0 Sistem yang Diusulkan

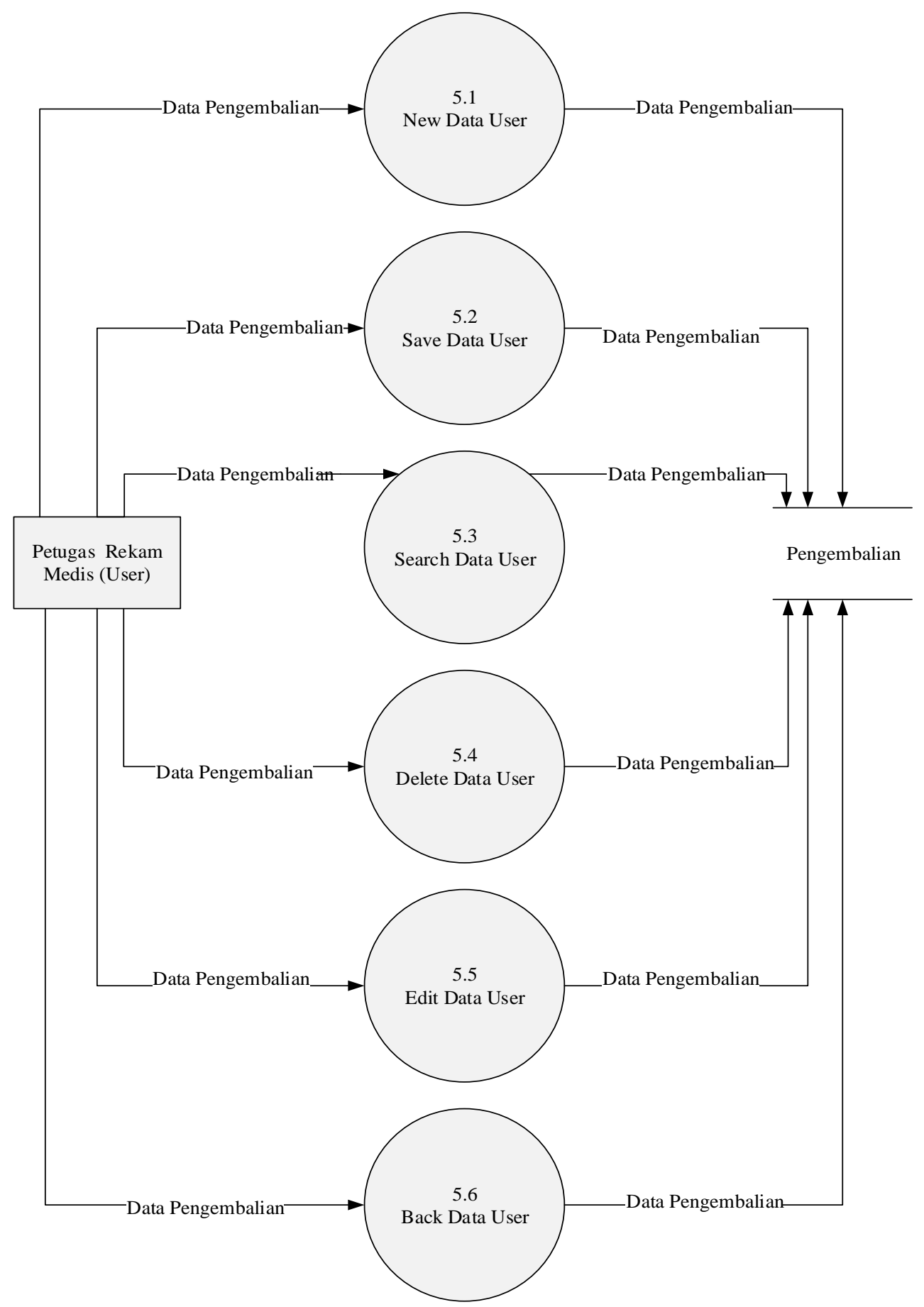

Gambar 10. DFD Level 1 Proses 5.0 Sistem yang Diusulkan 
9. DFD Level 1 Proses 6.0 Sistem yang Diusulkan

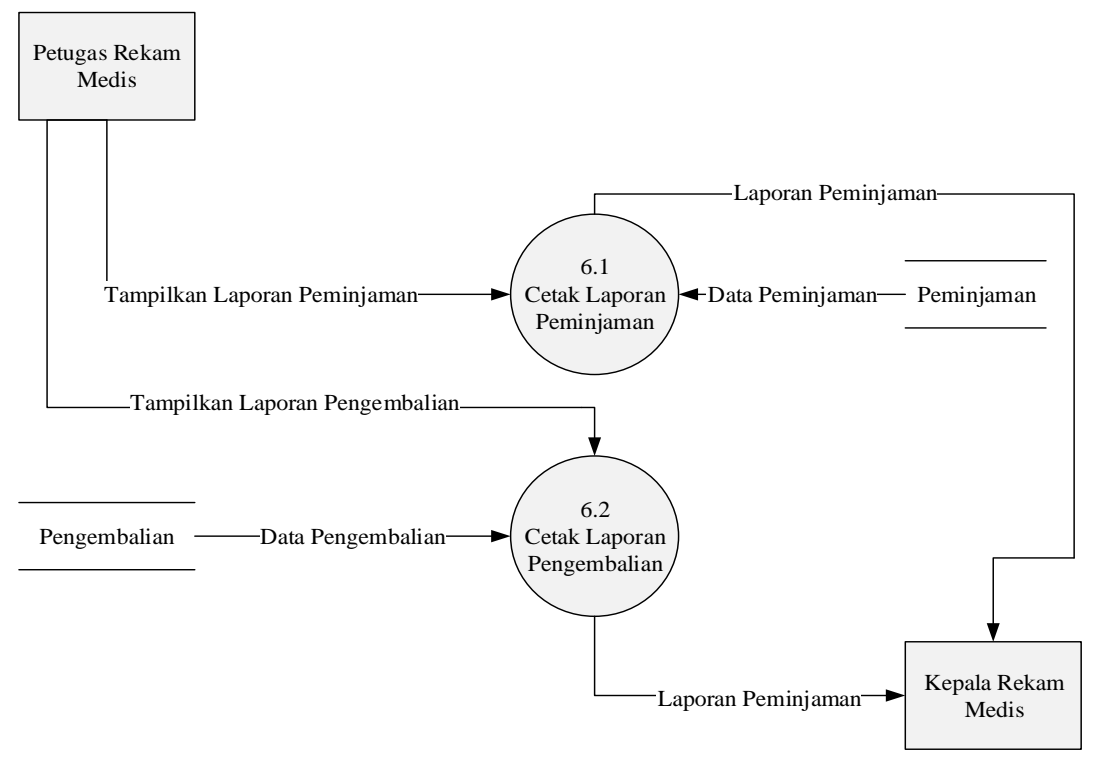

Gambar 11. DFD Level 1 Proses 6.0 Sistem yang Diusulkan

\section{Entity Relationship Diagram (ERD)}

ERD merupakan suatu model untuk menjelaskan hubungan antar data dalam basis data berdasarkan objek-objek dasar data yang mempunyai hubungan antar relasi (Pribadi et al., 2018). Berikut merupakan Entity Relationship Diagram (ERD) Sistem informasi peminjaman dan pengembalian rekam medis pasien rawat inap:

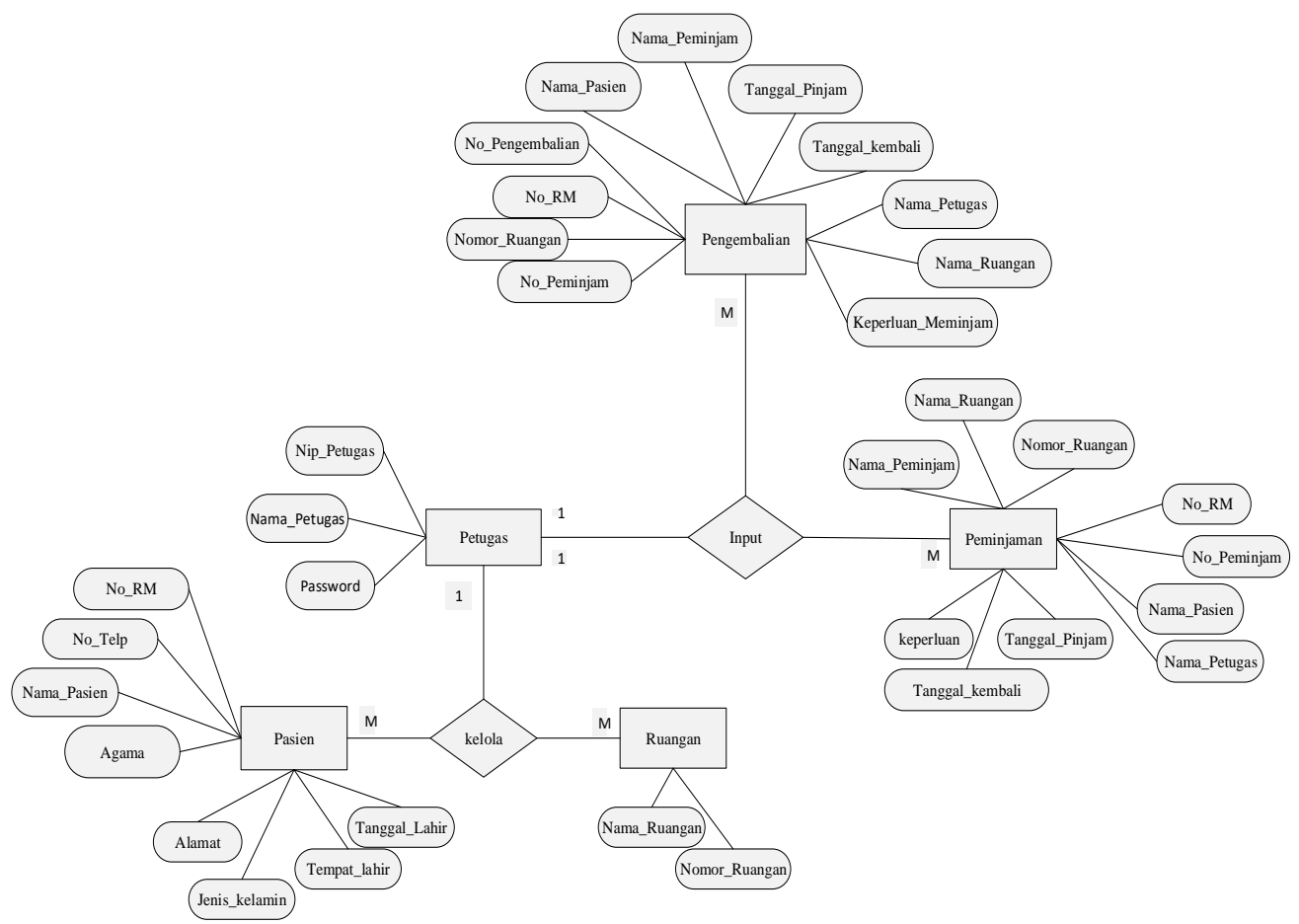

Gambar 12. Entity Relationship Diagram (ERD) 
11.Tabel Relasi Sistem Informasi Peminjaman dan Pengembalian Rekam Medis

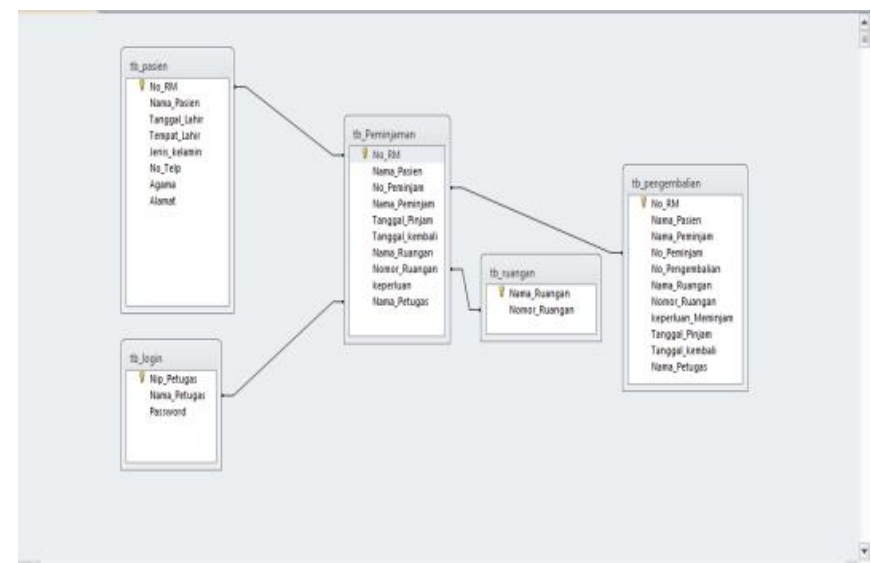

Gambar 13. Tabel Relasi

\section{Perancangan Sistem Yang Berjalan}

Perancangan proses yang dilakukan dari proses desain yang sudah dibuat kemudian diterapkan ke dalam sebuah program. Bahasa pemrograman menggunakan aplikasi Microsoft Visual Studio 2010 dan database menggunakan Microsoft Access 2010. Adapun tampilan-tampilan menu yang dibuat dan dirancang dalam sistem informasi peminjaman dan pengembalian rekam medis pasien rawat inap:

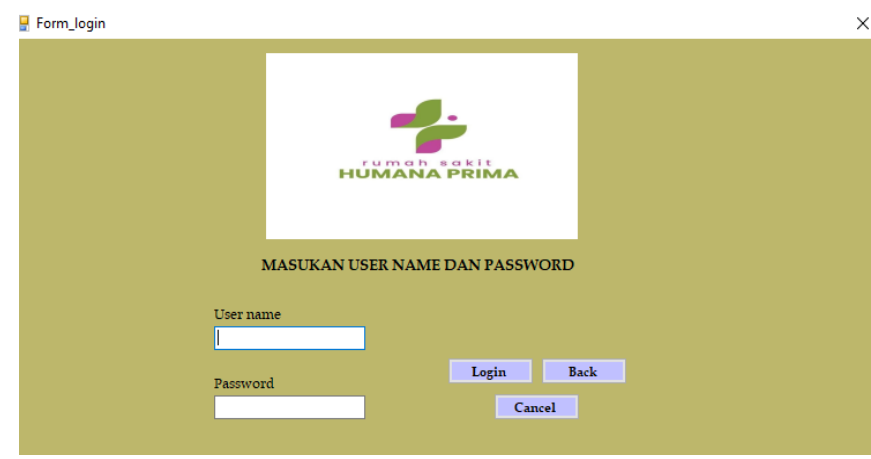

Gambar 14. Form Login

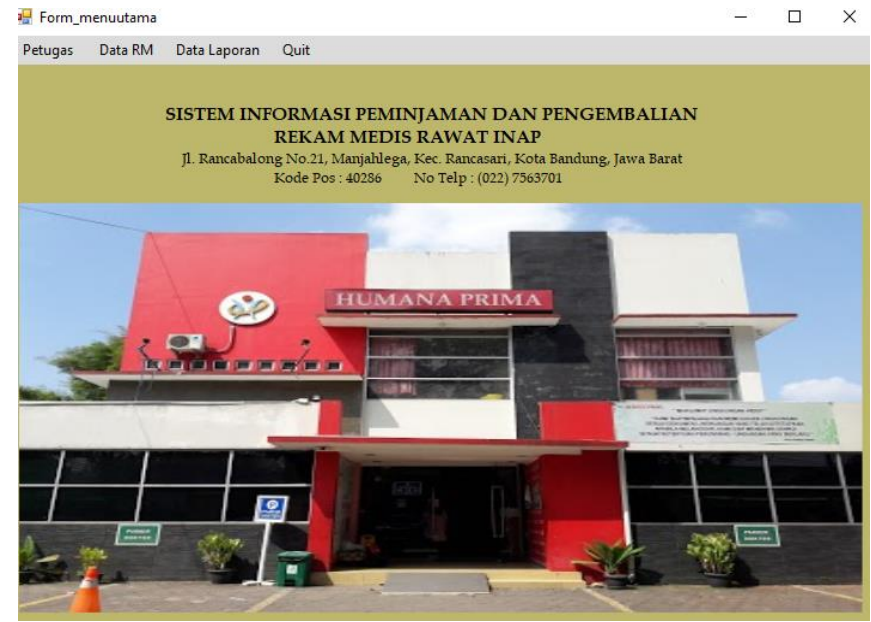

Gambar 15. Form menu utama 
Haini DwiJuliani Hendayal, Yuda Syahidin, Meira Hidayati /Cerdika: Jurnal Ilmiah Indonesia, 1(11), 1497 - 1515

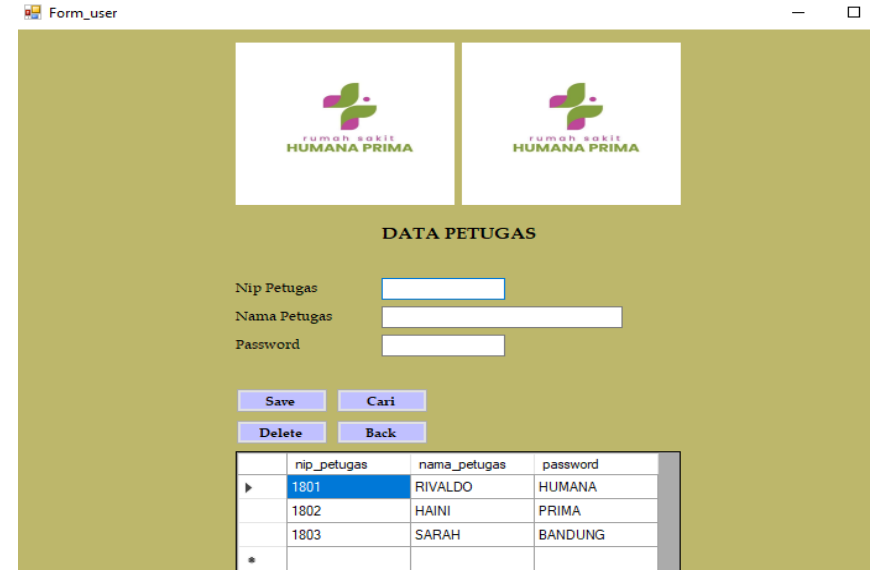

Gambar 16. Form User

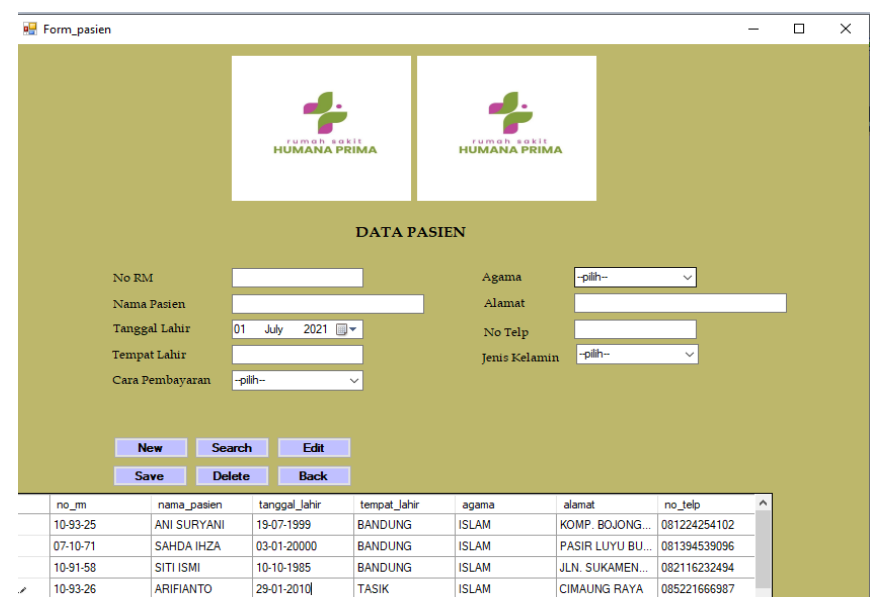

Gambar 17 . Form pasien

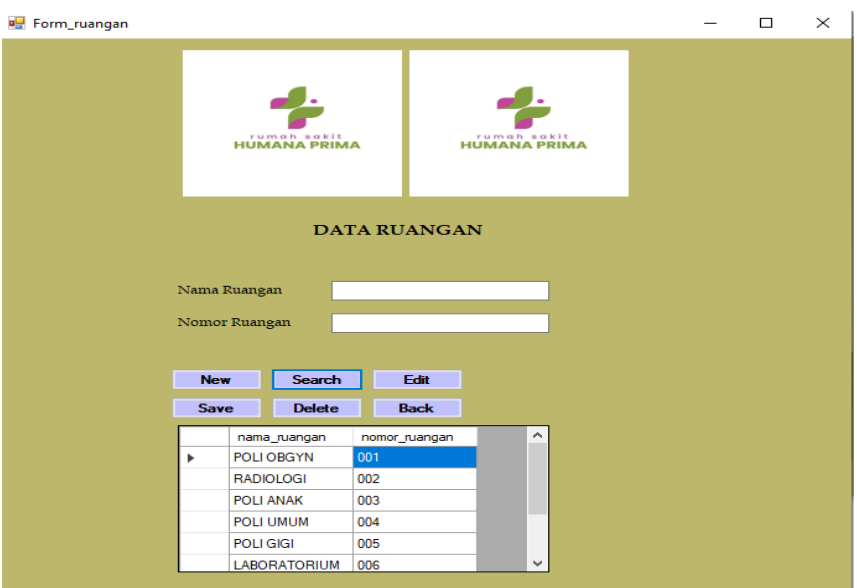

Gambar 18. Form Ruangan 
Haini DwiJuliani Hendayal, Yuda Syahidin, Meira Hidayati /Cerdika: Jurnal Ilmiah Indonesia, 1(11), 1497 - 1515

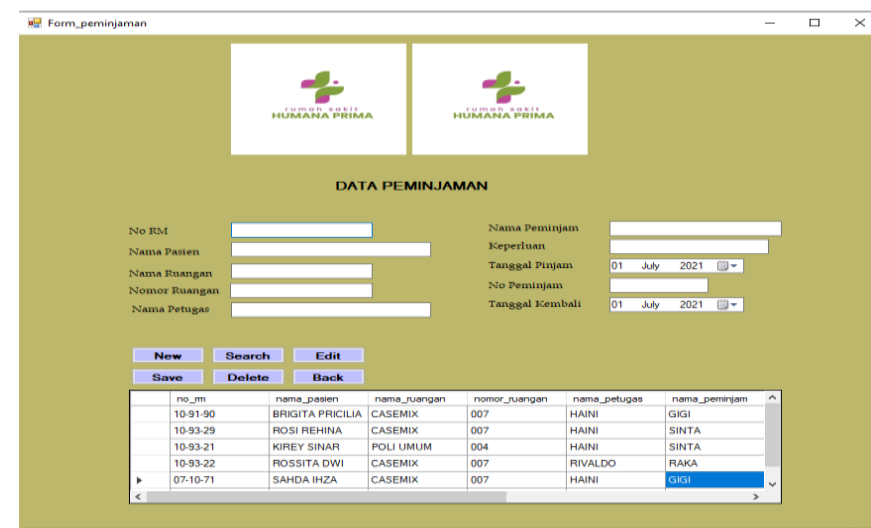

Gambar 19. Form peminjaman

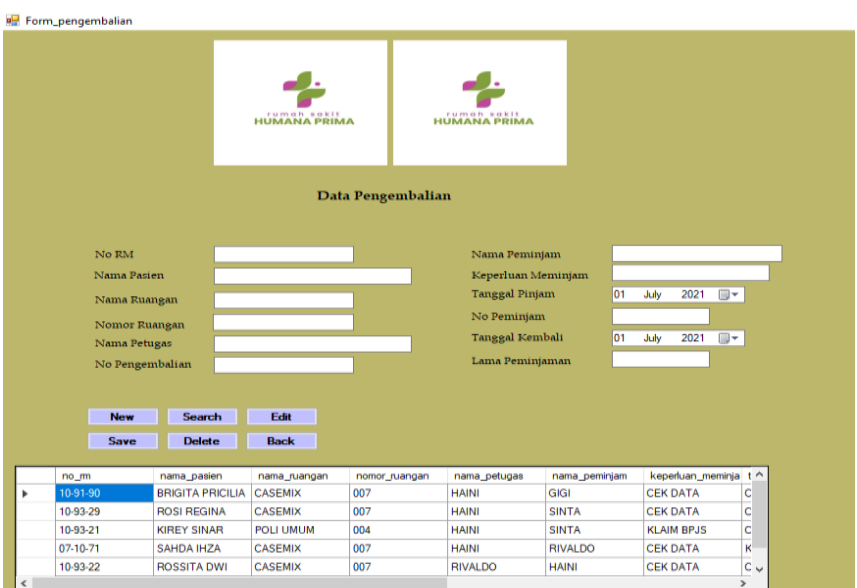

Gambar 20. Form pengembalian

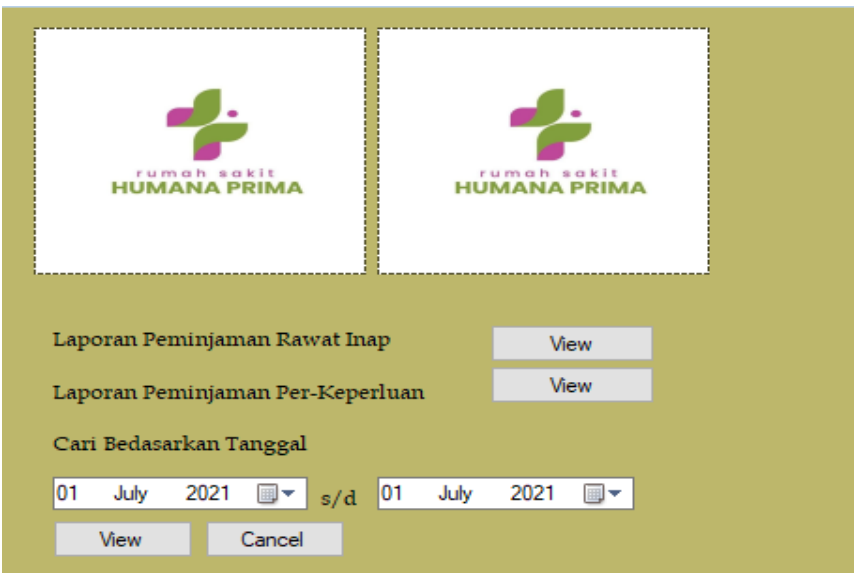

Gambar 21. Form laporan peminjaman 


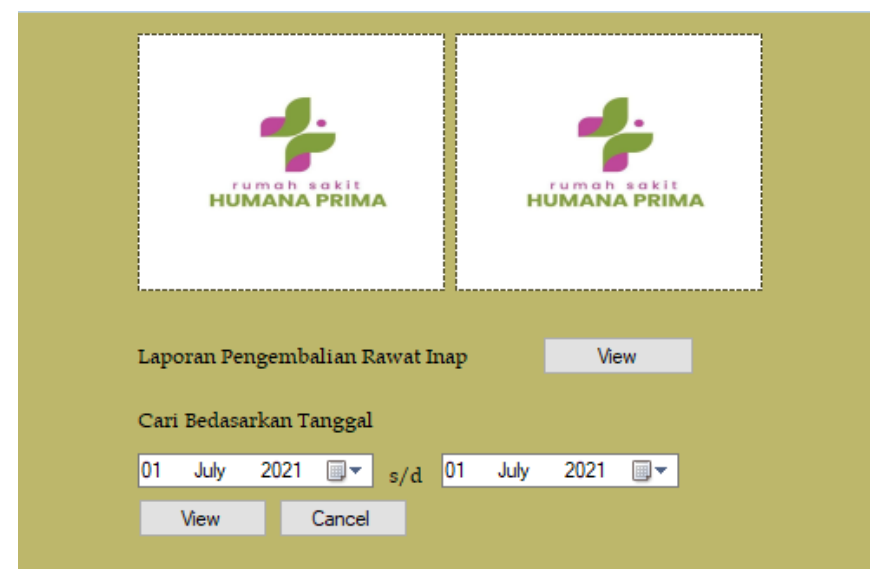

Gambar 22 . Form Laporan pengembalian

\begin{tabular}{|c|c|c|c|c|c|c|c|c|c|}
\hline & t & & & IA HUMANA PRI & MA BANDUNG & & & & \\
\hline & & & I1. Rancabalon & gg No.21, Manjahlega, Kec. & Rancasarri, Kota Bandur & ung, Jawa Barat & & & \\
\hline & & & & Kode Pos : 40286 & Telp : (022) 7563701 & & & & \\
\hline No RM & No Peminjam & Nama Ruangan & Nama Pasien & Cara Pembayaran & Nama Peminjam & Tanggal Pinjam & Tanggal Kembali & Keperluan & Nama Petugas \\
\hline $10-91-90$ & 00001 & CASEMIX & BRIGITA PRICILIA & BPJS KESEHATAN & GIGI & $18-07-2020$ & $18-07-2020$ & CEK DATA & HAINI \\
\hline 10-93-29 & 00002 & CASEMIX & ROSI REHINA & UMUM & SINTA & $18-07-2020$ & $18-07-2020$ & CEK DATA & HAINI \\
\hline 10-93-21 & 00003 & POLI UMUM & KIREY SINAR AIDA & BPJS KESEHATAN & SINTA & $18-07-2020$ & $18-07-2020$ & KLAIM BPJS & HAINI \\
\hline 10-93-22 & 00004 & CASEMIX & ROSSITA DWI & BPJS KESEHATAN & RAKA & $19-07-2020$ & $20-07-2020$ & CEK DATA & RIVALDO \\
\hline 10-93-25 & 00005 & CASEMIX & ANI SURYANI & BPJS KESEHATAN & GIGI & $21-07-2020$ & $24-07-2020$ & CEK DATA & HAINI \\
\hline 10-91-58 & 00006 & CASEMIX & SITI ISMI & BPJS KESEHATAN & GIGI & $23-07-2020$ & $23-07-2020$ & CEK DATA & SARAH \\
\hline $10-92-54$ & 00007 & POLI UMUM & FULKI FRASTIAN & UMUM & GIGI & $23-07-2020$ & $24-07-2020$ & CEK DATA & SARAH \\
\hline $04-37-20$ & 00008 & POLI ANAK & WINDY NOVA & BPJS KESEHATAN & RAKA & $25-07-2020$ & $26-07-2020$ & KLAIM BPJS & RIVALDO \\
\hline $10-48-08$ & 00009 & CASEMIX & RINI SURNANI & BPJS KESEHATAN & SINTA & $26-07-2020$ & $26-07-2020$ & KLAIM BPJS & RIVALDO 目 \\
\hline 10-93-26 & 000010 & POLI UMUM & ARIFIANTO ARIF & BPJS KESEHATAN & GIGI & $28-07-2020$ & $28-07-2020$ & CEK DATA & RIVALDO \\
\hline $10-93-32$ & 000011 & CASEMIX & DEDIMUL YANO & BPJS KESEHATAN & RAKA & $28-07-2020$ & $29-07-2020$ & CEK DATA & HAINI \\
\hline 10-93-23 & 000012 & CASEMIX & EL MUNIR & BPJS KESEHATAN & RAKA & $29-07-2020$ & $30-07-2020$ & CEK DATA & HAINI \\
\hline 10-93-24 & 000013 & POLI UMUM & TINA PRATIWI & BPJS KESEHATAN & RAKA & $31-07-2020$ & $31-07-2020$ & KLAIM BPJS & HAINI \\
\hline $09-42-85$ & 000014 & CASEMIX & DWI PUSPITA DEWI & UMUM & SINTA & $31-07-2020$ & $31-07-2020$ & CEK DATA & HAINI \\
\hline $07-10-71$ & 000015 & CASEMIX & SAHDA IZA & BPJS KESEHATAN & GIGI & $31-07-2020$ & $31-07-2020$ & CEK DATA & HAINI \\
\hline
\end{tabular}

Gambar 23 . Form Laporan Peminjaman

\begin{tabular}{|c|c|c|c|c|c|c|c|c|c|}
\hline & \multirow{3}{*}{+} & \multicolumn{5}{|c|}{ RSIA HUMANA PRIMA BANDUNG } & \multirow[b]{4}{*}{ Tanggal Kembali } & \multirow{2}{*}{$\&$} & \\
\hline & & \multirow[b]{3}{*}{ Nama Ruangan } & \multicolumn{4}{|c|}{ I1. Rancabalong No.21, Manjahlega, Kec. Rancasarri, Kota Bandưng, Jawa Barat } & & & \\
\hline & & & \multicolumn{4}{|c|}{ Kode Pos: 40286 No Telp : $(022) 7563701$} & & & \\
\hline No RM & No Peminjam & & Nama Pasien & Cara Pembayaran & Nama Peminjam & Tanggal Pinjam & & Keperluan & Nama Petugas \\
\hline 10-91-90 & 00001 & CASEMIX & BRIGITA PRICILIA & BPJS KESEHATAN & GIGI & 18-07-2020 & 18-07-2020 & CEK DATA & HAINI \\
\hline 10-93-29 & 00002 & CASEMIX & ROSI REHINA & UMUM & SINTA & 18-07-2020 & 18-07-2020 & CEK DATA & HAINI \\
\hline 10-93-21 & 00003 & POLI UMUM & KIREY SINAR AIDA & BPJS KESEHATAN & SINTA & 18-07-2020 & 18-07-2020 & KLAIM BPJS & HAINI \\
\hline 10-93-22 & 00004 & CASEMIX & ROSSITA DWI & BPJS KESEHATAN & RAKA & 19-07-2020 & $20-07-2020$ & CEK DATA & RIVALDO \\
\hline 10-93-25 & 00005 & CASEMIX & ANI SURYANI & BPJS KESEHATAN & GIGI & $21-07-2020$ & $24 \cdot 07-2020$ & CEK DATA & HAINI \\
\hline 10-91-58 & 00006 & CASEMIX & SITI ISMI & BPJS KESEHATAN & GIGI & $23-07-2020$ & $23-07-2020$ & CEK DATA & SARAH \\
\hline $10-92-54$ & 00007 & POLIUMUM & FULKI FRASTIAN & UMUM & GIGI & $23-07-2020$ & $24-07-2020$ & CEK DATA & SARAH \\
\hline $04-37-20$ & 00008 & POLI ANAK & WINDY NOVA & BPJS KESEHATAN & RAKA & $25-07-2020$ & $26-07-2020$ & KL.AIM BPJS & RIVALDO \\
\hline $10-48-08$ & 00009 & CASEMIX & RINI SURNANI & BPJS KESEHATAN & SINTA & $26-07-2020$ & $26-07-2020$ & KL.AIM BPJS & RIVALDO \\
\hline 10-93-26 & 000010 & POLI UMUM & ARIFIANTO ARIF & BPJS KESEHATAN & GIGI & $28-07-2020$ & $28-07-2020$ & CEK DATA & RIVALDO \\
\hline 10-93-32 & 000011 & CASEMIX & DEDI MUL YANO & BPJS KESEHATAN & RAKA & $28-07-2020$ & $29-07-2020$ & CEK DATA & HAINI \\
\hline $10-93-23$ & 000012 & CASEMIX & EL MUNIR & BPJS KESEHATAN & RAKA & $29-07-2020$ & $30-07-2020$ & CEK DATA & HAINI \\
\hline 10-93-24 & 000013 & POLIUMUM & TINA PRATIWI & BPJS KESEHATAN & RAKA & $31-07-2020$ & $31-07-2020$ & KLAIM BPJS & HAINI \\
\hline $09.42-85$ & 000014 & CASEMIX & DWI PUSPITA DEWI & UMUM & SINTA & $31-07-2020$ & $31-07-2020$ & CEK DATA & HAINI \\
\hline 07-10-71 & 000015 & CASEMIX & SAHDA IZA & BPJS KESEHATAN & GIGI & $31-07-2020$ & $31-07-2020$ & CEK DATA & HAINI \\
\hline
\end{tabular}

Gambar 24. Form Laporan Pengembalian

\section{Spesifikasi Software dan Hardware}

Spesifikasi Hardware yang digunakan untuk mengakses sistem informasi peminjaman dan pengembalian rekam medis di RSIA Humana Prima Bandung adalah sebagai berikut: 
1. Prosesor : Intel(R) Celeron(R) CPU N2920 @ $1.86 \mathrm{GHz}$

2. Memory : 4,00 GB (3,89 GB usable)

3. Monitor LCD

4. Mouse Standard

5. Keyboard

Spesifikasi Software yang digunakan untuk mengakses sistem informasi peminjaman dan pengembalian rekam medis di RSIA Humana Prima Bandung adalah sebagai berikut :

1. Sistem Operasi

: Windows 10

2. Bahasa Pemrograman

: Microsoft Visual Studio 2010

3. Database

: Microsoft Access 2010

\section{KESIMPULAN}

Berdasarkan hasil penelitian yang telah dilakukan maka dapat disimpulkan sebagai bahwasanya peminjaman dan pengembalian rekam medis pasien rawat inap di RSIA Humana Prima Bandung. Saat ini mempunyai pengolahan data yang cukup baik namun masih terdapat kendala untuk peminjaman dan pengembalian seperti sistem yang berjalan tidak sesuai dengan kenyataan yang ada dan membuat proses peminjaman dan pengembalian rekam medis dilakukan dengan cara manual. Begitupun dalam proses pengembalian rekam medis yang telah selesai dipinjam masih terjadi keterlambatan waktu pengembalian. Selain itu belum adanya sistem informasi peminjaman dan pengembalian rekam medis dengan laporan yang memadai sehingga sangat sulit untuk memonitoring.

\section{BIBLIOGRAFI}

Hutahaean, J. (2015). Konsep sistem informasi. Deepublish.

Indonesia, R. (2008). Peraturan Menteri Kesehatan Nomor 269/Menkes/Per/III/2008 Tentang Rekam Medis. Jakarta.

Indonesia, R. (2009). Undang-undang Republik Indonesia nomor 36 tahun 2009 tentang Kesehatan. Jakarta Republik Indones.

Jimmy Tri Pradana, G. (2019). Rancang Bangun Sistem Penyewaan Rental Mobil di Garuda Car Rental Berbasis Website Menggunakan Metode Waterfall. Universitas Muhammadiyah Jember.

Kasmawati, K. (2014). Pengaruh Lingkungan Kerja terhadap Kinerja Karyawan pada PT. Sermani Steel Makassar. Universitas Islam Negeri Alauddin Makassar.

Khanifatuzzahro, L., \& Kurniadi, A. (n.d.). Rancangan Sistem Informasi Pencatatan Asuhan Keperawatan Berbasis Elektronik di RSUD Kota Semarang Tahun 2015.

Noviasari, T., Sugiarsi, S. R. I., \& Kusumawati, Y. (2016). Hubungan kelengkapan informasi dengan persetujuan klaim BPJS di RSUD Kabupaten Sukoharjo Tahun 2016. Universitas Muhammadiyah SurakartA.

Pribadi, T. S., Baidawi, T., \& Marlina, S. (2018). Sistem Informasi Administrasi Nikah Berbasis Web Pada KUA Bantar Gebang Bekasi. Simnasiptek 2015, 1(1), 105-111.

Putra, C. S. (2019). Peranan Teknologi Informasi dalam Pelayanan Keperawatan di Rumah Sakit. Simtika, 2(3), 28-31.

Rikomah, S. E. (2017). Farmasi Rumah Sakit. Deepublish.

Rosalin, A. D., \& Herfiyanti, L. (2021). Ketepatan Pengembalian Rekam Medis Pasien Rawat Inap di Rumah Sakit Mitra Siaga Tegal. Cerdika: Jurnal Ilmiah Indonesia, 1(7), 775-783.

Setiatin, S., \& Syahidin, Y. (2017). Perancangan Sistem Informasi Penyimpanan Rekam Medis Rawat Inap Berbasis Elektronik. Jurnal Manajemen Informasi Kesehatan

Perancangan Sistem Peminjaman dan Pengembalian Rekam Medis Rawat Inap Rumah Sakit Humana Prima Bandung 
Haini DwiJuliani Hendayal, Yuda Syahidin, Meira Hidayati /Cerdika: Jurnal Ilmiah Indonesia, 1(11), 1497 - 1515

Indonesia (JMIKI), 5(2), 181-194.

Wijayanti, A. P., Epriyani, I. W., \& Fiskasari, E. (2021). Perancangan Sistem Informasi Kohort Ibu Hamil Menggunakan Microsoft Visual Studio 2010 Di Upt Puskesmas Paseh Kabupaten Bandung. Jurnal INFOKES (Informasi Kesehatan), 5(1), 1-16.

Yanuar, Y. (2017). Perancangan Sistem Informasi Kelengkapan Pengisian Formulir Informed Consent DI RS Al Islam Bandung. Jurnal E-Komtek (Elektro-KomputerTeknik), 1(1), 112-131.

(C) 2021 by the authors. Submitted for possible open access publication under the (c) (7) (2) terms and conditions of the Creative Commons Attribution (CC BY SA) 